Forthcoming in HOPOS: The Journal of the International Society for the History of Philosophy of Science, 2020: https://doi.org/10.1086/707909

This is the submitted version: Please quote from the reviewed and published version

\title{
Descriptive Psychology: Brentano and Dilthey
}

\section{Guillaume Fréchette (Salzburg/Geneva)}

\begin{abstract}
Although Dilthey and Brentano were apparently pursuing roughly the same objective - to offer a description of our mental functions and of their relations to objects - and both called their respective research programmes 'descriptive psychology', they seem to have used the term to refer to two different methods of psychological research. In this paper, I discuss some analyses of these differences. Against (Orth 1984), but also against a possible application of recent relativist accounts of the epistemology of peer disagreement to this case, I argue that their apparent shared objective is not strong enough to support an understanding of their views as two alternatives within a given historical or scientific context or as a mutual peer disagreement. I show that the impression of a shared objective can in fact be explained away by some influences from the psychology of their teacher Trendelenburg, and I stress that the case of introspection strongly suggests that an account in terms of peer disagreement is not plausible. Finally, I conclude that the opposition between two traditions, Austrian philosophy and historicism, might be better suited to account for the dispute and its apparent common historical context.
\end{abstract}

\section{Similarities, dissimilarities, and the context}

Brentano and Dilthey both developed at around the same time the idea that psychology as the science of the mind should be based on a discipline which starts from experience and takes phenomena and their regularities as its starting point. They both argued that this discipline, namely descriptive psychology (henceforth DP), should be sharply distinguished from genetic or explanatory psychology, which seeks to provide causal explanations, ideally of 
psychophysical nature, for the phenomena experienced. ${ }^{i}$ From this general perspective, it makes sense to see the projects of Dilthey and Brentano regarding DP as directed at basically the same goal. This seems at least to have been Husserl's view on Dilthey and Brentano, as both played a crucial role in setting him on the path that led him to phenomenology. ${ }^{\mathrm{ii}}$

Other students of Brentano were more skeptical of the alleged convergence of Brentano and Dilthey in this respect. As (Kraus 1927) stresses, for example, the regularities of the mental as conceived by Brentano and by Dilthey are only superficially similar. For Brentano, these regularities are laws governing the relations between the parts of the mental at a time, while for Dilthey, they are understood as a structural context (Strukturzusammenhang) which involves a teleological dimension (Zweckzusammenhang) and is absent from Brentano's idea of the regularities of the mental accessible to DP.

Another dissimilarity between the views of Brentano and Dilthey pertains to the methodology proper to DP. While Brentano defends the idea that the method of philosophy (and by extension of DP) is nothing more than the method of natural science, Dilthey argues that DP is a human science (Geisteswissenschaft) which follows its own method, distinct in kind from that of natural science. Dilthey's dictum, "We explain nature, but we understand the life of the soul," is unacceptable to Brentano: like explanation, understanding is nothing but a kind of knowledge. We may very well accept a distinction between kinds of knowledge (e.g., empirical vs. a priori, or by explanation vs. by understanding) without introducing a corresponding distinction between disciplines. From this methodological perspective, the divergence between Dilthey and Brentano seems unbridgeable.

While there is evidence that supports understanding Brentano's and Dilthey's projects as convergent, there are also good reasons to stress the fundamental differences between them. An historically and systematically plausible account of their respective views should therefore take both the similarities and dissimilarities into account. Here, different options are available. The first is to deny any substantial convergence, as suggested recently in (Damböck 
2017, 111ff.). According to Damböck, Brentano’s focus on inner perception and his aprioristic world-view, in the lines of Bolzano, Lotze, and Frege (as Damböck suggests) would make him an advocate of a view completely foreign to Dilthey's empiricism. I have doubts about this theoretical reconstruction of Brentano's project, but more importantly, Damböck's take on the issue forces him to minimize or ignore the historical factors (and their theoretical relevance) supporting the convergence between the two projects, which is a suboptimal strategy in this context.

Another option presents itself here, which is to see their agreement and disagreement from a relativist perspective. On this view, one could say that Dilthey and Brentano were basically defending different 'cornerstone beliefs' about DP (Kusch 2018), or were involved in a 'systematic peer disagreement' (Goldberg 2013) that would entitle them to stick to their views. A relativist historian of philosophy looking at this disagreement might be able to explain some apparent similarities by reference to historical context, 'situations', or 'transformations' that occurred at certain moments in the history of philosophy. In the case of Dilthey and Brentano, this has already been proposed by (Orth 1984), who suggests that “what is remarkable in Dilthey's and Brentano's solutions is that they want to face the situation in which they are. This means that they take up the scientific culture as it has developed and, correspondingly, deal with the questions of natural science and human science, with experience and history" (Orth 1984, 33). ${ }^{\text {iii }}$

While the relativist view so understood makes sense both of Husserl's confession and of the discrepancies between the views of Dilthey and Brentano, it still posits, when accounting for apparent similarities (in Orth's case at least), spatiotemporal entities such as 'situations' or 'transformations' which seems to serve as the stable background against which the disagreement occurs. Such a postulate also affects one's understanding of the disagreement itself: if it is already granted that the context conditions the similarities, it would be implausible to restrict its role in the explanation of dissimilarities or disagreements. Thus, 
if the context determines the disagreements as well, then the fact that two opponents hold different beliefs in the face of the same body of evidence (in this case, for instance: that the data provided by one's experience is relevant for DP) could license a relativist perspective on the disagreement, as (Kusch 2018) suggests.

I have two concerns about the prospects of the relativist perspective in the case at hand. First, I doubt that the historical context, or spatiotemporal entities such as 'situations' and 'transformations' can provide an explanation of the similarities that are revealed. In fact, they can be explained by shared ideas that Dilthey and Brentano inherited from the same source. In section 3, I propose to explain these similarities in terms of the influence on both Dilthey and Brentano of Adolf Trendelenburg, who taught them both in Berlin in the 1850s and 1860s.

Second, I doubt that the conflict between Dilthey and Brentano on DP can rightly be understood as a "reasonable, mutually recognized peer disagreement" (Hazlett 2014). Obviously, Dilthey's rejection of Brentanian psychology on the basis of its reliance on introspection suggests that the two opponents were not dealing with the exact same body of evidence: for Dilthey, it seems that the empirical data delivered by inner experience can't serve as evidence for our beliefs about the nature of mind, as they do in Brentano's psychology. I will discuss this in section 4, before concluding in section 5 with my proposal on how to understand this particular disagreement about DP.

\section{The origins of descriptive psychology}

Before going back to the common source explaining their similarities, it might be useful first to look at the origins of descriptive psychology - both the term and the concept - in Germany and Austria in the second half of the nineteenth century, but also at how Dilthey and Brentano relate their own projects to the history of philosophy. What strikes one first is that the label seems to have emerged from different sources, ranging from British empiricism to Herbartian 
psychology. Looking at the sources to which Brentano and Dilthey trace their respective conceptions of DP strengthens this impression: Dilthey's own reflections on DP from 1894 (Dilthey 1894, 1324ff.) suggest that his own conception of DP (or beschreibende Psychologie) goes back to the Herbartian Theodor Waitz (Waitz 1852). He not only credits Waitz with the introduction of the distinction between descriptive and explanatory psychology, but also stresses that Waitz was the first to see the importance of descriptive psychology for anthropology, and for comparative study involving the "history of the development of individuals and society" (Dilthey 1894, 1325). Waitz considered DP a part of the sciences of organic life, encompassing description, analysis, and classification but also comparison and a theory of evolution (Entwicklungslehre). It is under this latter aspect that his anthropology of indigenous populations (Anthropologie der Naturvölker) was meant as a contribution to DP. ${ }^{\text {iv }}$

Interestingly, anthropology is for Waitz not only part of DP, but also the common factor of two "extremely different disciplines" (äußerst verschiedene Fächer) and methods of human knowledge: "the anatomy, physiology and psychology of man on the one hand, and cultural history with all its connected sciences on the other" (Waitz 1859, 4). In his appraisal of Waitz, Dilthey was obviously aware of this methodological distinction, which prefigures his own distinction between the natural and the human sciences. Given Dilthey's own conception of DP as a human science concerned with the forms of lived experience and their expression in society and culture, it is easy to understand why Dilthey saw in Waitz the origins of what in 1894 he calls descriptive psychology. ${ }^{\mathrm{v}}$

Waitz clearly played a role in the introduction of the term and the concept of descriptive psychology in philosophical works written in German in the second half of the nineteenth century. Philosophers trained by Brentano were aware that Waitz used the expression 'descriptive psychology', but they denied any connection between what they call descriptive psychology and the kind of investigations proposed by Waitz under the same 
name, which are best understood as "a kind of psychological painting similar to what is provided by the poets.",vi

Brentano and his students are less explicit than Dilthey when it comes to identifying their sources. In Brentano's early manuscripts, however, there is some discussion of Whewell's distinction between explanatory-causal (aetiological) and descriptive (phenomenological) sciences. ${ }^{\text {vii }}$ Even in his lectures on descriptive psychology from 1887/88, Brentano implicitly refers to Whewell's distinction by using his analogy of the relation between geognosy and geology to illustrate the distinction between descriptive and aetiological sciences, which Brentano appeals to for his distinction between descriptive and genetic psychology. ${ }^{\text {vii }}$

Brentano's first systematic application of this distinction between descriptive and explanatory sciences to psychology appears in the draft of the third book of his Psychology from an Empirical Standpoint, which he wrote in 1875 but left unfinished, and which is still unpublished:

Regarding presentations, we have to solve a twofold problem: we must describe them and determine the laws to which they are subject in their origins and development. Description seems to be a relatively easy task. But even there, philosophers differ considerably from one another. The disunity is such that even the existence of whole classes is disputed. What makes the investigation especially difficult is the indistinctness or lack of distinctness of a presentation. Every description contains, as John Stuart Mill rightly emphasized, more than perception: it contains comparison and interpretation. ${ }^{\text {ix }}$

Here, as in many other places, Brentano's references regarding the importance of description in scientific investigations are clearly to be found not in German psychologists but in British 
Empiricism. It seems therefore reasonable to believe that in their own respective selfunderstandings, Dilthey and Brentano associated DP with different kinds of investigation and different historical backgrounds.

To be sure, Waitz and Whewell (and Mill) are probably not the only sources of Dilthey's and Brentano's uses of the term and concept of DP, ${ }^{\mathrm{x}}$ but these different sources may serve as an indicator of the difference between the projects pursued by Dilthey and Brentano. In Brentano's case, DP is in continuity with the idea that the method of philosophy is the same as the method of natural science. DP, which Brentano also calls phenomenology, falls under the same principle. Not only should metaphysical investigations be conducted according to scientific methods - that is, according to the methods developed by the empirical sciences of the time, much in line with the conceptions of philosophy defended by Mill, Whewell and Comte - but phenomenology too, as a part of such investigations, should follow the same principles.

In his lectures on descriptive psychology of $1887 / 88$, Brentano becomes more explicit about a distinction that remained implicit in his Psychology of 1874, namely, the distinction between descriptive and genetic psychology. In these lectures, descriptive psychology is likened to an anatomy of the elements of the mental, while genetic psychology is likened to a physiology of its functions. This distinction between elements and functions is an important innovation in Brentano's phenomenology in 1887. While the analysis of the elements of the mental can be carried out exclusively by descriptive psychology, the analysis of their functions involves "psychophysical investigations", which have to be carried out by genetic psychology.

That there must be some kind of priority of descriptive psychology over genetic psychology becomes clear when one takes literally the analogy with the relation between anatomy and physiology suggested by Brentano. That is, in order to explain certain functions of the mind, we need to identify first what they are functions of: physiology needs anatomy in 
the same sense as genetic psychology needs descriptive psychology. This is what Brentano seems to have in mind in the 1887 lectures:

If it were so easy to do descriptive psychology, the difficulty would have been solved long ago, whereas we rather have to begin from the very start. Signs of disagreement and divergence of views. Indeed, in important aspects the prevalence of such views which, as we shall see, reveal the most decisive errors. On the other hand, many points that are of the greatest interest have not yet at all become an object of attention. Everything is rudimentary, unfinished, chaotic. Of course it is a special obstacle, indeed the greatest one, for more significant advances of genetic psychology - which has to fulfill such challenging tasks. Sad labyrinths of many psychophysicists. (Brentano, forthcoming)

What kind of priority is at stake here? What Brentano seems to suggest is that one should first clean up the theoretical problems in descriptive psychology if one wants to get good results in genetic psychology. If this is the case, the kind of priority involved seems mainly procedural, in the sense that it relates to the ordering of the steps necessary for successfully conducting the overall project of philosophy as a science.

Genetic psychology on the other hand seeks to find the laws of psychophysical nature. The situation of genetic psychology is unfortunately still embryonic: since we currently have only a limited knowledge of the laws of genetic psychology, we still have to rely on psychical laws such as the laws of the succession or coexistence of mental states. In this respect, the situation of genetic psychology is similar to that of Kepler, ${ }^{\mathrm{xi}}$ who had only empirical laws of the movement of planets until Newton was able to deduce the laws of their movement from the laws of gravitation. In some sense, it seems that inexact empirical laws are only second best, since, for the time being at least, we do not have exact psychophysical laws from which 
we could deduce genetic psychology. In fact, Brentano seems not to believe that such exact psychophysical laws are obtainable; rather, they should be seen as an ideal of genetic psychology, although such an ideal is in practice unattainable for the simple reason that exact measurements of intensities seem impossible. Thus, notwithstanding the differences between descriptive and genetic psychology, they do follow the same method.

What about Dilthey? Obviously, he believed that DP is the basic human science, the task of which is to find the law of structure "through which intelligence, the life of drives, affective life, and voluntary actions are connected to an organic whole of the life of the soul" (Dilthey 1894/1924, 92). DP is the "description and analysis of a context (Zusammenhang) which is always originally given as life itself' (ibid.). The mental structural context (Strukturzusammenhang) is at the same time a teleological one (zugleich ein teleologischer), which is "conditioned by the position of the unity of life (Lebenseinheit) within a milieu" (Dilthey 1894/1924, 212), with which it stands in interaction. Ultimately, the role of DP for Dilthey is to build a bridge between the study of individuality and the historical world. Here, Dilthey's debt to Waitz's conception of DP is hard to deny: the scope of Dilthey's DP, which investigates the teleological nature of the mental structural context within a milieu, resembles Waitz's project of an anthropology embedded in DP.

In their objectives and origins, the projects of Dilthey and Brentano, despite some structural similarities, are in fact quite different. It is true that both see DP as an investigation of the structure of the mental, but their agreement on this point is rather superficial. According to Dilthey, the whole of the mental has a teleological structure and is conditioned by its interactions within a milieu. For Brentano, such a claim goes beyond what can actually be said from a descriptive psychological perspective; self-evident experience only provides us with mental acts at a time and cannot disclose any teleological features in our experience. These few points should suffice to show that the similarities between the views of Dilthey and Brentano on DP cannot be satisfactorily explained by reference to a historical context, or to a 
'situation'. It is clear that they developed their views on DP starting from different influences.

\section{Assessing the similarities: Trendelenburg}

Given the different sources and objectives of DP for Brentano and Dilthey, it might seem reasonable to account for the superficial similarities between their views by positing a historical context or some situation that they both had to face. However, such a postulate has little explanatory power, and less than the identification of a common source of influence. Looking to Trendelenburg as a common source of influence is not particularly far-fetched: after all, both Dilthey and Brentano acknowledged Trendelenburg's influence in their autobiographical writings and they both were his students in Berlin in the 1850 s and 1860 s. ${ }^{\text {xii }}$

Brentano attended Trendelenburg's lectures on psychology in 1858/59, and the lecture transcripts available today were made by Brentano. ${ }^{\text {xiii }}$ It is not exactly clear whether Dilthey attended the same lectures as Brentano at an earlier time or at the same time, or only some of them. Some of his diary entries from 1858 and 1859 suggest however that he attended lectures given by Trendelenburg in the same period as Brentano and that Trendelenburg shared some of his manuscripts with Dilthey. ${ }^{\text {xiv }}$ Not only do we find echoes of Trendelenburg's lectures in Dilthey's diaries, but we also find them in Dilthey's early writings on psychology, in Brentano's early metaphysics lectures of 1867 , and in the drafts of the second and third volumes of the Psychology from an Empirical Standpoint.

Brentano took extensive notes on Trendelenburg's lectures on psychology in 1858/59. In these lectures, Trendelenburg lays out the "twofold task of psychology" (Die doppelte Aufgabe der Psychologie) as follows:

The soul stands between nature and the spiritual world (geistige Welt); the flower of the former is the seed of the latter. Psychology therefore has a twofold task: 1. the understanding (Verständnis) of nature in its purpose (Zweck); 2. The understanding 
of the spiritual world in its impulse (Antrieb). Psychology appears to us as the pinnacle of natural science and as the basis of ethics; it establishes the transition from physics to ethics. ${ }^{\mathrm{xv}}$

What is striking here is the similarity between Trendelenburg's conception of the twofold task of psychology and some of Dilthey's descriptions of the tasks of DP - for instance, in the drafts to the second volume of Einleitung (Dilthey 1982, 100), where psychology is said to study the "interaction between the unity of life with the external world in the transfer of impression, which acts effectively from the external world, and impulse (Antrieb), which reacts on it". ${ }^{\mathrm{vvi}}$ As in Trendelenburg, the spiritual world (in Dilthey: the unity of life) interacts with nature in terms of impulse (Antrieb).

In the same lectures, Trendelenburg sometimes cashes out the idea of an interaction between the two tasks of psychology in terms of "interpenetration" (Durchdringung), ${ }^{\mathrm{x} v i i}$ but he speaks of "interaction" (Wechselwirkung) to describe the teleological unity of organic life:

The concept of an organism must lead us to the discovery of the reality of the soul. The organism is a collection of tools (parts), each one of which bears its purpose in itself and thus bears the highest purpose of the whole. The purpose is the idea of a future action (Wirkung) which determines the direction of a force (Kraft). The hand has the purpose of grasping, the eye the purpose of seeing. When Aristotle says that the whole is prior to the parts, he means that every part has its relation to the whole, and that the whole as unity is the purpose of the parts. [...] The whole has itself as a purpose, wants to preserve itself, and needs the tools for it. [...] We have an interaction of the parts which, by conditioning themselves reciprocally, condition the whole. In the nexus effectivus, we have only a temporal series of causes and effects, but here we have interaction, and this is the main distinction between the causa 
finalis and the causa efficiens. ${ }^{\mathrm{x} v i i}$

The teleological nature of the interaction between the parts (or tools) in the whole (or purpose) has some similarity with Dilthey's conception of the 'context of effectivity' (Wirkungszusammenhang), as described especially in the Aufbau (Dilthey 1910 [GS VII], 147ff.). While for Dilthey, "it is the structure of the spirit in its Wirkungszusammenhang, on the basis of apprehension, to produce values and to realize purposes", which he calls the "immanent teleological character of the spiritual Wirkungszusammenhänge" (Dilthey $1910 / 1927,186)$, Trendelenburg suggests that the teleology at play in the interaction of the parts or tools of the organism leads us to the teleology of the soul: the spiritual world's interaction with nature in terms of impulse seems to suggest that there is a similar teleology in the spiritual world.

Brentano imported elements from Trendelenburg's teleological account of the partwhole relation into his early metaphysics around 1867 :

The formal parts are themselves subject to degrees. They are either integrative or non-integrative. A part is integrative when its absence would mean mutilation. Only where there is purpose, as there is in organisms, can one find such parts. [...] Thus the meaning of formal parts increases with the increasing importance, and in an even higher and stricter sense those parts are formal which are connected with the organic life, e.g., heart, brain. Others, like the hand, are not formal in this sense. [...] The explanation that we are giving is a teleological one. ${ }^{\text {xix }}$

Interestingly, the teleological account of the part-whole relation is absent from the writings on psychology and seems not to be developed further in later versions of his metaphysics lectures. Given the importance of Trendelenburg for the early Brentano, it seems reasonable 
to believe that Trendelenburg's teleological interpretation of Aristotle's conception of the priority of the whole over the parts is at the origin of the teleological ideas discussed in his 1867 lectures on metaphysics.

Finally, the historical dimension of the spiritual world, which is stressed by Dilthey in many of his works, is also a point that Trendelenburg emphasizes at various points in his psychology lectures:

The spiritual world. Here, we find the natural, the individual transformed into the general and abstract. Writings, money, names. Function $(A m t)$, profession, religion, state [have] a great influence on man. Man is a zoon politikon, but in the same way one can call him a historical being, since he is not only in connection with the present, but with all times. ${ }^{\mathrm{xx}}$

I quote these passages from Trendelenburg's lectures on psychology from 1858/59 in order to show that some ideas developed there were adopted by both Dilthey and Brentano, although in different ways. While the teleological view of the relation between the parts and the whole seems to have left a strong impression on both Dilthey and Brentano, it seems that the idea of an interaction between the spiritual world and nature in terms of a reactive impulse of the former on the latter and the historical dimension of the spiritual world stressed by Trendelenburg left a lasting impression on Dilthey, but no significant traces in Brentano's published writings and manuscripts. Finally, the idea that psychology faces the twofold task of accounting for nature while also accounting for the spiritual world in its 'impulse' might well be the general insight that led Brentano and Dilthey to distinguish between the explanatory and descriptive tasks of psychology. I do not dispute that the convergent understanding of Brentano's and Dilthey's projects expressed in Husserl's autobiographical remark and explained by Orth in terms of a shared 'situation' has a substantive meaning: what 
I want to suggest here is that this meaning can probably be spelled out best in terms of the influence of their common teacher Trendelenburg.

\section{The case of introspection}

I suggested in the first section that the relativist view of the agreement and disagreement between Dilthey and Brentano had the advantage of being able to account for the superficial convergence of their views on DP without affecting their 'cornerstone beliefs'. At least in Orth's account of the disagreement, the price to pay for this advantage was the positing of historical entities such as situations, or historical contexts, which condition significantly the nature of the disagreement. I showed in the last section that it is possible to account for the similarities without presupposing a historical context; in fact, as I suggested, Trendelenburg's views on psychology clearly inspired both Dilthey and Brentano, and this common source of influence can plausibly account for the similarities. In this case, there is no need for a relativist account.

Let me now turn to my second concern about the relativist account of the disagreement. Seeing the opposition between Dilthey and Brentano on DP as a "reasonable, mutually recognized peer disagreement" presupposes, as stressed earlier, that both of them were dealing with the same body of evidence. When it comes to disagreement over philosophical methodology, what seems to play the role of a common body of evidence are shared metaphilosophical assumptions on the nature of valid arguments, proofs, causality, justification, belief, knowledge, etc. In the case of the disagreement between Dilthey and Brentano, it is reasonable to suppose that they share at least some of these general metaphilosophical assumptions, but for a reasonable, mutually recognized peer disagreement in this case, we need specific metaphilosophical assumptions related to DP. What could they be? The assumption that the empirical data delivered by our experience serves as evidence for our beliefs about the nature of mind? As we already have seen in the last sections, it is 
disputable whether Dilthey and Brentano have the same understanding of 'empirical data' and 'experience'. Therefore, it is questionable whether we are really facing here a mutually recognized peer-disagreement. In fact, their respective views on the nature of introspection suggest that this supposition is implausible.

One of the central tenets of Dilthey's conception of DP is the rejection of introspection as an unreliable method. Not only does introspection have too much influence on the results and the experiences (Dilthey 1924a, 317-18; Dilthey 1927, 319), but it is also short-sighted about the depth of experience itself: "An expression of lived experience can contain more of the nexus of psychic life than any introspection can catch sight of. It draws from depths not illuminated by consciousness" (Dilthey 1910/1921, 227). Regarding the first point, introspection would lead to the creation of entities and processes which are not actually present in experience. This seems to be the motivation behind Dilthey's critique of Brentano's psychology in the Aufbau: "After the natural scientific atomistic psychology came the school of Brentano, which is psychological scholasticism. For they created abstract entities, and behaviours, object, and content, from which they want to compose life. Husserl is here an extreme case" (Dilthey 1927, 237).

As (Kraus 1927, 498) emphasized against Dilthey, the Brentanians believe that only actually occurring mental acts are introspectible in a reliable way. Like Dilthey, and for the same reasons, they reject introspection understood in a broader sense, ${ }^{\mathrm{xxi}}$ i.e. in the sense of a deliberate act of observation of one's past mental acts. Past mental acts, most Brentanians argue, are not accessible with the self-evidence of actually occurring acts and therefore are not an epistemically secure source for psychological investigations. In attributing to the Brentanians a psychology that creates entities on the basis of a too strong reliance on introspection, and in also discarding introspection as being too short-sighted for the depths of the nexus of psychic life, Dilthey's beliefs about introspection seem to be not merely in contradiction with Brentano's beliefs: rather, what Dilthey considers introspection to be and 
what Brentano considers it to be are obviously two different things, which suggests that they do not have access to the same body of evidence. Furthermore, in the case of Dilthey at least, it seems that the nexus of psychic life is something we experience, and which is over and above the unity of consciousness which is experienced in inner perception according to Brentano. Therefore, it seems hard to identify a body of evidence which would be shared by Brentano and Dilthey in their disagreement and which would be specific enough to make a "reasonable, mutually recognized peer disagreement" possible.

\section{An alternative}

If the points emphasized in the two last sections are correct and the relativist perspective is suboptimal for an understanding of the disagreement over DP, how do these claims or beliefs relate to one another and what should be the proper understanding of Dilthey's and Brentano's disagreement over DP? The alternative I propose is this: it seems to be a relatively unproblematic claim that philosophy in German-speaking countries in the second half of the nineteenth century is divided into different streams, branches, or traditions. Now, these traditions, like historical contexts or situations, are also spatiotemporal entities. The difference between a tradition and a historical context, however, is that the tradition contains, in addition to its merely spatiotemporal features, a body of beliefs which have some independence from the spatiotemporal features. These include specific metaphilosophical assumptions as the ones mentioned above, but also definitions, analyses, and basic philosophical intuitions.

Consider as an example the hermeneutic-historical tradition coming from Herder and Humboldt and developing from Schleiermacher to Dilthey. Within the body of beliefs of this tradition, we find the idea of the autonomy of the historical world: everything which happens in history should be explained within history and with the help of historical methods. We also find the idea that everything which exists in the human world (the state, society, morals, institutions, etc.) is a constitutive part of history, and is not eternal but depends on the context. 
We can call these claims a) the autonomy of the historical world claim and b) the contextdependency of human reality claim. These two claims are not spatiotemporal features of the historicist tradition, since they can in principle be shared by philosophers coming from other traditions. They are not exhaustive neither: they do not necessarily capture the hermeneutichistorical tradition in its entirety. Such claims like (a) and (b) have a twofold function: they constitute the content of the tradition of which they are part, but they also serve as a heuristic device to individuate the tradition.

Consider now the tradition of Austrian philosophy. It also includes a body of beliefs that help to individuate this tradition: i) the rejection of the Kantian distinction between the analytic and the synthetic (Bolzano 1837); ii) the rejection of the Kantian distinction between categories and concepts (Bolzano 1837); iii) the nativist claim that space is given in perception (Hering 1864; Brentano 1907); iv) the claim that value is determined in terms of needs and availability (Menger 1871, Ehrenfels 1887, Meinong 1894); v) the claim that the method of philosophy is the same as the method of the natural sciences (Brentano 1866); vi) the importance of precise definitions in argumentation (Hillebrand 1884 against Dilthey 1883); vii) the need for more accurate psychological claims in theory of knowledge (Stumpf 1891); and viii) the rejection of instincts and the focus on communication intentions in order to explain the origins of language (Marty 1884-1892), just to mention a few. Here too, claims (i) - (viii) have the same twofold function as claims (a) and (b).

We rejected the relativist account of the disagreement over DP in terms of a 'reasonable, mutually recognized peer disagreement' for the reason that Dilthey and Brentano don't share the same body of evidence, i.e. the same set of metaphilosophical claims. For some philosophical disputes, for instance disputes about the existence and nature of qualia in experience, one could reasonably say that they share the same body of evidence in this sense. However, the disagreement over DP is different: it is a disagreement over the proper methodology for psychology (and philosophy, by extension) as a science. Here, the heuristic 
function of the metaphilosophical claims should not be underestimated: they also are used to show that the specific disagreement at play here is an instance of a larger disagreement between two competing traditions. This clearly plays a role in both in Brentano's and Dilthey's overall projects.

Let's take a further case to illustrate this, the Methodenstreit between Menger and Schmoller which, as a matter of fact, was seen both by Dilthey and the Brentanians as another battlefield of a larger disagreement. Here too, some basic similarities in their conceptions are certainly undeniable, for both Menger and Schmoller want to account for the nature of national economy in considering empirical reality. But what they consider empirical differs greatly: for Menger, what is empirically given in economy are individual human actions, while for Schmoller, it is society as a whole. Here again, a relativist account of the Methodenstreit framing the debate in terms of 'reasonable, mutually recognized peer agreement' would have to identify a common body of evidence. And as was the case with the debate over DP, one would have to say that the body of evidence is constituted by (among other things) incompatible claims about the nature of experience - a conclusion that the relativist cannot accept.

In order to frame the Methodenstreit or the disagreement about DP in terms of a 'reasonable, mutually recognized peer agreement', the relativist has to reject the thesis that the body of evidence is constituted at least partly by claims of the sort mentioned above. What could then serve as evidence is disputable, but it seems that whatever her answer to this question is, it will not allow her to categorize the Methodenstreit and the disagreement over DP as instances of a more fundamental conflict between two traditions. Of course, she could say that Schmoller's attacks on Menger and his references to Dilthey in the debate are to be explained politically and institutionally, and she could say the same about Hillebrand's defence of Menger (Hillebrand 1884) and his attack on Dilthey's Einleitung. But she would have to admit, at least for the case in question, that a relativistic account of a disagreement 
which involves a relativist and a non-relativist will, for obvious reasons, favour one side of the disagreement over the other.

The account I am proposing here presupposes only the existence of traditions, which are spatiotemporal entities related to some set of claims. In the specific case of the disagreement about DP, I suggested that the impression of a 'reasonable, mutually recognized peer disagreement' was due to the superficial similarities between Dilthey's account of DP and Brentano's. My point in section 3 was to show that these similarities are not based on some historical context or situation, but on the influence that Trendelenburg exerted on both Dilthey and Brentano. This specific case is obviously not generalizable to all philosophical and metaphilosophical disputes; it does, however, suggest that a relativist account of these in terms of 'reasonable, mutually recognized peer disagreement' faces some difficulties at least in the case of metaphilosophical disputes. ${ }^{x x i i}$

\section{References}

Bolzano, Bernard. 2014. Theory of Science (4 vols). Transl. Rolf George and Paul Rusnock. Oxford: Oxford University Press.

Bona Meyer, Jürgen. 1870. Kant's Psychologie. Berlin: Wilhelm Hertz.

Brentano, Franz. 1907. Untersuchungen zur Sinnespsychologie. Leipzig: Duncker \& Humblot.

Brentano, Franz. 1874. Psychologie vom empirischen Standpunkte. Leipzig: Duncker \& Humblot.

Brentano, Franz. 1895. Meine letzten Wünsche für Österreich,.Stuttgart: Cotta.

Brentano, Franz. 1982. Deskriptive Psychologie, Hamburg: Meiner.

Brentano, Franz, 1995. Descriptive Psychology. Transl. Benito Müller. London: Routledge.

Brentano, Franz. 2015. Psychology from an empirical Standpoint. Transl. Linda McAlister. London: Routledge.

Brentano, Franz. Forthcoming. Deskriptive Psychologie und Beschreibende Phänomenologie. Vorlesungen 1887/88 und 1888/89. Dordrecht: Springer.

Bühler, Karl. 1927. Die Krise der Psychologie. Jena: Fischer. 
Damböck, Christian. 2017. Deutscher Empirismus: Studien zur Philosophie im deutschprachigen Raum 18301930. Cham: Springer.

Deimling, Otto. 1851. Der Philosophische Unterricht auf der Mittelschule; ein pädagogisches Votum. Mannheim: Kaufmann.

Dilthey, Wilhelm. 1883/1914. Einleitung in die Geisteswissenschaften. Versuch einer Grundlegung für das Studium der Gesellschaft und der Geschichte. Erster Band. [Gesammelte Schriften I] edited by. Bernhard Groethuysen. Leipzig: Teubner.

Dilthey, Wilhelm. 1921. Studien zur Geschichte des deutschen Geistes. Leibniz und sein Zeitalter. Friedrich der Grosse und die deutsche Aufklärung. Das achtzehnte Jahrhundert und die geschichtliche Welt. [Gesammelte Schriften III] Edited by Paul Ritter. Leipzig: Teubner.

Dilthey, Wilhelm. 1894. „Ideen über eine beschreibende und zergliedernde Psychologie.“ Sitzungsberichte der königlich preussischen Akademie der Wissenschaften zu Berlin, philosophisch-historische Classe 44:1309-1407. Reedited in Dilthey (1924) [Gesammelte Schriften V], pp. 139-240.

Dilthey, Wilhelm. 1924. Die geistige Welt. Einleitung in die Philosophie des Lebens. Erste Hälfte: Abhandlungen zur Grundlegung der Geisteswissenschaften. [Gesammelte Schriften V] Edited by Georg Misch. Leipzig: Teubner.

Dilthey, Wilhelm. 1924a. Die geistige Welt. Einleitung in die Philosophie des Lebens. Zweite Hälfte:

Abhandlungen zur Poetik, Ethik und Pädagogik. [Gesammelte Schriften VI] Edited by G. Misch. Leipzig: Teubner.

Dilthey, Wilhelm. 1910/1927. Der Aufbau der geschichtlichen Welt in den Geisteswissenschaften, Reimer, Berlin. Reedited in Gesammelte Schriften VII in Leipzig: Teubner.

Dilthey, Wilhelm. 1982. Grundlegung der Wissenschaften vom Menschen, der Gesellschaft und der Geschichte. Ausarbeitungen und Entwürfe zum zweiten Band der Einleitung in die Geisteswissenschaften (ca. 1870.1895). [Gesammelte Schriften XIX]. Edited by Hans Johach and Frithjof Rodi. Göttingen: Vandenhoeck \& Ruprecht.

Ehrenfels, Christian. 1887. Über Fühlen und Wollen. Eine psychologische Studie. Vienna: Kaiserliche Akademie der Wissenschaften.

Fries, Johann Friedrich. 1807. Neue Kritik der Vernunft. Erster Band. Heidelberg: Mohr und Zimmer. Goldberg, Sanford C. 2013. "Inclusiveness in the face of disagreement.” Synthese 190: 1189-1207. Hazlett, Allan. 2014. "Entitlement and mutually recognized reasonable disagreement." Episteme 11: 11-25. Hering, Ewald. 1864. Beiträge zur Physiologie. Leipzig: Engelmann. 
Husserl, Edmund. 1952. Ideen zu einer reinen Phänomenologie und phänomenologischen Philosophie. Zweites Buch: Phänomenologische Untersuchungen zur Konstitution. Edited by Marly Biemel. Den Haag: Martinus Nijhoff.

Hillebrand, Franz. 1884. "Über einen neuen Versuch zur Grundlegung der Geisteswissenschaften." Zeitschrift für das Privat- und öffentliche Recht der Gegenwart 11: 632-642.

Kraus, Oskar. 1927. „Geisteswissenschaft und Psychologie. Methodologisch-kritische Betrachtungen.“ Euphorion 28: 497-519.

Kusch, Martin. 2018. “Disagreement, Certainties, Relativism.” Topoi. Online: https://doi.org/10.1007/s11245018-9567-z

Meinong, Alexius. 1894. Psychologisch-ethische Untersuchungen zur Werth-Theorie. Graz: Leuschner \& Lubensky.

Menger, Carl. 1871. Grundsätze der Volkswirthschaftslehre. Vienna: Braumüller.

Martinelli, Riccardo. 2018. "Defining human sciences: Theodor Waitz's influence on Dilthey." British Journal for the History of Philosophy 26: 498-518.

Marty, Anton. 1884. “Über Sprachreflex, Nativismus und absichtliche Sprachbildung.” Vierteljahrsschrift für wissenschaftliche Philosophie 8: 456-478 (1st article).

Marty, Anton. 1886. “Über Sprachreflex, Nativismus und absichtliche Sprachbildung.” Vierteljahrsschrift für wissenschaftliche Philosophie 10: 69-105 (2nd article); 346-364 (3rd article).

Marty, Anton 1889. “Über Sprachreflex, Nativismus und absichtliche Sprachbildung.” Vierteljahrsschrift für wissenschaftliche Philosophie 13:195-220 (4th article); 304-344 (5th article).

Marty, Anton. 1890. “Über Sprachreflex, Nativismus und absichtliche Sprachbildung.” Vierteljahrsschrift für wissenschaftiche Philosophie 14: 55-84 (6th article); 442-484 (7th article).

Marty, Anton. 1891. “Über Sprachreflex, Nativismus und absichtliche Sprachbildung.” Vierteljahrsschrift für wissenschaftliche Philosophie 15: 251-284 (8th article); 445-467 (9th article).

Marty, Anton. 1892. “Über Sprachreflex, Nativismus und absichtliche Sprachbildung.” Vierteljahrsschrift für wissenschaftliche Philosophie 16: 104-122 (10th article).

Marty, Anton. 1894[2011]. Deskriptive Psychologie, edited by Mauro Antonelli and Johann Christian Marek. Würzburg: Königshausen \& Neumann.

Misch, Clara. (ed.) 1960. Der junge Dilthey. Ein Lebensbild in Briefen und Tagebüchern 1852-1870. second edition, Stuttgart-Göttingen. 
Oberkofler, Gerhard. (ed.) 1989. Franz Brentano. Briefe an Carl Stumpf 1867-1917. Graz: Akademische Druckund Verlaganstalt.

Orth, Ernst Wolfgang. 1984. „Wilhelm Dilthey und Franz Brentano zur Wissenschaftsforschung.“ Phänomenologische Forschungen 16: 24-54.

Riehl, Alois. 1887. Der philosophische Kriticismus und seine Bedeutung für die positive Wissenschaft. Zweiter Band, zweiter Teil (Schluss): Zur Wissenschaftstheorie und Metaphysik. Leipzig: Engelmann.

Waitz, Theodor. 1852. „Der Stand der Parteien auf dem Gebiete der Psychologie.“ (2 articles) Allgemeine Monatssschrift für Wissenschaft und Literatur, Jahrgang 1852. Braunschweig: Schwetschke \& Sohn: 872888; 1003-1026.

Waitz, Theodor. 1859. Anthropologie der Naturvölker. Band 1: Erster Theil: Über die Einheit des Menschengeschlechtes und den Naturzustand des Menschen. Leipzig: Fleischer.

Whewell, William. 1840. The Philosophy of the Inductive Sciences, Founded upon their History. Volume 1. London: Parker.

Zimmermann, Robert. 1851. "Schriften über philosophische Propädeutik." Zeitschrift für die österreichischen Gymnasien 2: 395-408.

\section{Archive materials}

Brentano, Franz. EL75: Zur Logik. Altes Logikkolleg vor 1874. Houghton Library, Harvard University.

Brentano, Franz. Ps53: Psychologie (Fragment des geplanten III. Bandes der ,Psychologie vom empirischen Standpunkt‘, Houghton Library, Harvard University.

Brentano, Franz. 1867b, Metaphysik. Vorlesung 1867. Houghton Library, Harvard University. Transcription by W. Baumgartner et al. (Universität Würzburg, Adolf-Würth Zentrum für die Geschichte der Psychologie). Trendelenburg, Friedrich Adolf. 1858/59. [TLP] Psychologie, Nachschrift von Franz Brentano, Franz-Brentano Archiv, Universität Würzburg (Adolf-Würth Zentrum für die Geschichte der Psychologie). Edition by W. Baumgartner, forthcoming in Brentano-Studien XV/2 (2019).

\footnotetext{
${ }^{\mathrm{i}}$ Compare for instance (Dilthey 1883/1914, 32-33) with (Brentano 1982) on the goals of descriptive psychology and on the distinction between descriptive and explanatory (or genetic) psychology.

ii (Husserl 1952, 313)

iii Here and throughout this paper, the English translations from the German are mine. I leave the German original in footnotes only for quotes from unpublished German manuscripts.

iv See for instance the six volumes of his Anthropologie der Naturvölker (Waitz 1859ff).

v On Waitz's influence on Dilthey, see (Martinelli 2018).

${ }^{v i}$ German original: "eine Art psychologischer Malerei, wie sie der Dichter gibt". Quoted from (Marty 1894[2011], 7 and 172ff.), who quotes (Waitz 1852, 852ff.) to stress the fundamental differences between Brentano's and Waitz's concepts.
} 
vii See (Brentano EL75, 12921-12).

viii Compare (Brentano 1982/1995, 6/7-8); (Brentano 1895, 34) with (Whewell 1840, 101). Brentano annotated the German translation of (Whewell 1840).

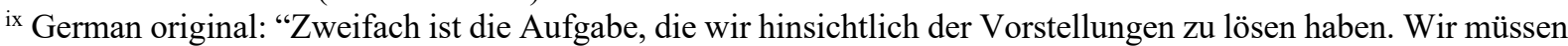
sie beschreiben und die Gesetze feststellen, welchen sie in ihrer Entstehung und in ihrem Verlaufe unterworfen sind. Die Beschreibung scheint die relativ leichte Aufgabe. Dennoch weichen auch hier die Philosophen weit voneinander ab; ja die Uneinigkeit ist so groß, daß über die Existenz ganzer Classen gestritten wird. Was die Untersuchung besonders schwierig macht, ist die Undeutlichkeit oder mangelhafte Deutlichkeit der Vorstellung. Jede Beschreibung enthält, wie John Stuart Mill mit Recht hervorhebt, mehr als die Wahrnehmung, sie enthält Vergleich und Deutung" (Brentano, Ps53: 53003).

${ }^{x}$ The term was used by various authors in the nineteenth century, for instance in Bona Meyer's book on Kant's psychology (Bona Meyer 1870, 295), but also in (Deimling 1851, 8), (Zimmermann 1851, 398), in (Fries 1807, xlix) and (Riehl 1887, 256). It cannot be ruled out that Dilthey and Brentano were aware of these works.

${ }^{x i}$ The very same point is made in (Brentano 2015, 79).

xii On Brentano on Trendelenburg, see Brentano's biographical letter to the Prussian Academy of Sciences from 1914, published in (Oberkofler 1989), ix-x: "With Trendelenburg, I shared all my life the conviction that philosophy is capable of a truly scientific approach, but that it is incompatible with such an approach when, without any reverence toward the ideas transmitted by the great thinkers of earlier times, it aims to insert them anew in every head. Therefore, I followed his example when I dedicated some years of my life to the study of the works of Aristotle, which he taught me to consider as an unexploited treasure trove". On Dilthey on Trendelenburg, see Dilthey's allocution from 1903 on the occasion of his seventieth birthday (Dilthey [GS V, 7ff.]): "Here, I recall my teacher and friend Trendelenburg, who had the greatest influence on me, before any other. Today one can no longer imagine the strength of his position back then. It was due to the fact that he connected to a whole the facts of the history of philosophy carefully studied, and that this whole had the effect of a living force on his audience." xiii An edition of Trendelenburg's lectures of psychology from 1858/59 (henceforth TLP) based on Brentano's script is forthcoming in Brentano Studien (XV/2, 2019). I thank Wilhelm Baumgartner for his permission to quote from this material.

xiv See (Misch 1960).

${ }^{x v}$ TLP, German original: "Die Seele steht in der Mitte der Natur und geistigen Welt; die Blüte der einen der Keim der andern. Die Psychologie hat daher eine doppelte Aufgabe 1. das Verständnis der Natur in seinem Zwecke, 2. das V[erständnis] der geistigen Welt in ihrem Antriebe. Sie erscheint uns als Gipfel der Naturwissenschaft und Basis der Ethik, sie bildet den Übergang von der Physik zur Ethik."

xvi Dilthey 1982, 100. German original: "Wechselwirkung der Lebenseinheit mit der Außenwelt im Umsatz von Eindruck, der aus der Außenwelt wirkend eintritt, und Antrieb, der auf sie zurückwirkt".

xvii TLP, German original: "Wir unterscheiden rationale und empirische Psychologie. Letztere sollte eine Ergänzung der ersteren sein. [...] Das Beste ist Durchdringung von Rationalem und Empirie."

xviii TLP, German original: "Der Begriff des Organismus muss uns weiterführen zur Entdeckung der Realität der Seele. Der Organismus ist ein Inbegriff von Werkzeugen (Teilen), deren jedes seinen Zweck in sich trägt, er trägt daher in sich den höchsten Zweck des Ganzen. Der Zweck ist die Idee einer künftigen Wirkung, die die Richtung einer Kraft bestimmt. Die Hand hat den Zweck, dass sie greife, das Auge den, dass es sehe. Wenn Aristoteles sagt, das Ganze sei vor den Teilen, so meint er, jeder Teil habe seine Beziehung zum Ganzen, das Ganze als Einheit ist Zweck der Teile. Das Ganze bezweckt sich, will sich erhalten, und dazu bedarf es der Werkzeuge. [...] Wir haben eine Wechselwirkung der Teile, sich gegenseitig bedingend und das Ganze bedingend. Beim nexus effectivus haben wir nur eine Zeitreihe von Ursachen und Wirkungen, hier aber ist Wechselwirkung und diese ist eine Hauptunterscheidung der causa finalis von der causa efficiens."

xix Brentano, Metaphysik Vorlesung, §606. German original: "Die formalen unterliegen wieder Abstufungen. Sie sind integrierend oder nichtintegrierend. Integrierend ist ein Teil dessen Mangel Verstümmelung wäre. Nur wo Zweck ist, wie in den Organismen, können solche Teile sein. So steigt aber die Bedeutung der formalen Teile mit der wachsenden Wichtigkeit, und in einem noch höheren und engeren Sinn sind daher jene Teile formal, an welche das organische Leben gebunden ist z.B. Herz, Gehirn. Andere wie die Hand sind in dem Sinne nicht formal. [...] Die Erklärung, die wir geben, ist eine teleologische."

xx TLP, German original: "Die geistige Welt. Wir finden hier das Natürliche, Individuelle ins Allgemeine, Abstrakte verwandelt; Schrift, Geld, Personennamen. Großen Einfluss auf den Menschen hat Amt, Beruf, Religion, Staat. Der Mensch ist zoon politikon, ebenso kann man ihn ein historisches Wesen nennen; denn er steht nicht bloß mit der Gegenwart, er steht mit allen Zeiten in Verbindung."

xxi (Bühler 1927, 110ff.) made a similar point against Dilthey's student Spranger.

xxii Many thanks to the three anonymous reviewers of this paper and to the participants of the Völkerpsychologie and descriptive psychology conference in Vienna in 2017 for their feedback during the discussion. This paper has been written as part of the FWF project P-272015 on Brentano's descriptive psychology. 